\section{PARASITES AND PARASITISM}

\section{Platyhelminthes and Parasitism}

An Introduction to Parasitology. By D. R. R. Burt. Pp. viii $+150+11$. (English Universities: London, September 1970.) $45 s$ boards; $28 s$ paper.

THIs small book is written in a crisp and direct style and it is a useful introduction to the study of flatworms and parasitism, the essential nature of which brings into the picture various Protozoa and Arthropoda.

The book has an introduction and ten brief chapters with many miniature sections which express certain essentials in a succinct manner. Such abbreviation of any study of parasites and parasitism must produce inadequate and sometimes objectionable statements, but the general tone of the book indicates circumspection and a serious attempt to simplify complex matters with a minimum of distortion. The chapters deal respectively with classification, the host as environment, parasitic Turbellaria, the Monogenea, the Aspidogastrea, the Digenea, the "Didymozoonidea", the Cestodaria, the Cestoda, and host-parasite relations. They have chapter heading aphorisms, and I was amazed to find my name among those of such notabilities as Hadrian, Coleridge, William Blake, Lewis Carroll, Robert Burns, Erasmus Darwin, Nowton and others. There are many clear line diagrams and eleven not so clear plates, which augment points made in the text.

The classification adopted is objectionable because it is brief and irregular, and there are other slight irritations; for example the consideration of suckers and other haptors simply as adhesive organs when in reality they are more often efficient accessory locomotor organs. Any student in Britain who watches Gyrodactylus move swiftly across the gill or fin of a fish host, or any student in the Antipodes who watches Temnocephala move over the crustacean host's integument by means of a sucker and tentacles, will nover need reminding that haptors are of great utility in translatory motion. My chief irritation concerns the term "oncomiracidium" (hooked young) of Monogenea; these larvac have no power of multiplication within a host, as have the miracidia of digenetic trematodes, and "oncomiracidium" is a misnomer. I also noted a few error's such as the term "scolices" for "scoloces", and (at least a dozen times) the wrong naming of Aspidogaster conchicola.

But in spite of incompleteness of statement, comparison and exposition, a fow errors and misconceptions, the author of this book deserves praise for exciting wonderment in the reader and indicating where further information can be found. The list of recornmended sources of information will give the reader much food for thought and endeavour, if studied, but because it has appeared annually there is no reason for calling Advances in Parasitology a "journal" when it is a succession of books. Lastly, the index is useful and accurate, and figures are indicated in bold face type. Dr Burt is to be congratulated for a small but significant addition to the literature on parasitism.

Ben Dawes

\section{GONADAL HORMONES}

\section{The Gonads}

Edited by K. W. McKerns. (Biochemical Endocrinology Series.) Pp. xv+792. (North-Holland: Amsterdam; Appleton-Century-Crofts (Educational): New York, 1969.) $328 s ; 140 \mathrm{Hfl}$.

THIs second monograph in the "Biochemical Endocrinology Series" deals with the pathways of steroidogenesis of the ovary and testis and the regulatory effect of gonadotrophins on cellular processes. Data are presented on the mechanism of action of gonaclotrophins on steroid synthesis, on the activation and induction of enzymes, on the synthesis of RNA and of protein. Many excellent techniques are described for studying the intact in situ testis and for slices and homogenates of gonads, and for the transplanted ovary.

The book is divided into three parts. Part one, which is by far the largest section, deals with functions of the ovaries and consists of fifteen chapters, each written by a top expert in his respective field. This part covers a very wide spectrum of research, including regulation of steroidogenesis in the ovaries, synthesis of progestational steroids, regulation of ovarian function by gonadotrophins, transplantation of the ovary into the eye, studies on the mechanism of luteinization, and a concept of a uterine luteolytic hormone. As stated by McKerns in his chapter on the regulation of ovarian function by gonadotrophins, the growth of follicles and formation of corpora lutea seem intimately associated with the changing pattern of steroidogenesis, but further complications arise because the ovary is regulated by so many trophic hormones that it is difficult to answer the question whether growth and steroidogenesis are regulated by trophic hormones as separate mechanisms. Hormones of the follicles and interstitial tissue may also effect the function of the corpora lutea, and the ubiquitous cyclic nucleotide $3^{\prime} 5^{\prime}$ AMP would seem to have an associated role in trophic hormone action, thus making this question of growth even more difficult to answer. Whatever the mechanism proposed for a trophic hormone, the tremendous advance in knowledgo portrayed in these chapters has posed more questions than answers.

Part two contains an excellent chapter on steroid secreting cells, particularly gonadal cells. The last part deals with the initiation and maintenance of sperm. atogenesis in the testis and the effect of ionizing radiations on the organ. The seven chapters in this section are all first class, and there is a wealth of information about androgen production by the testes. Again, more questions are posed than answered. It seems that little is known about storoid secretions, if any, in the epididymus of animals.

This is a rewarding book; it is rather expensive, but it is worth every penny. Areas of research are covered which are of very great interest to all reproductive endocrinologists, biologists, physiologists and biochemists. I hope the series will continue. Donald ExLEY

\section{ISLAND VOLCANOES}

\section{Volcanism and the Upper Mantle}

Investigations in the Kurile Island Are. By Georgii S. Gorshkov. Translated from the Russian by Charles P. Thornton. (Monographs in Geoscience.) Pp. $x v+385$. (Plenum: London and New York, April 1970.) (\$35.00; $327 s$.

There has been much interest lately in island arcs, not least because they have been shown to form a transition between the continents and occan basins and because of the part they are alleged to play in the plate tectonic theory of continental drift. The author, a Russian volcanologist of international standing, has spent some twenty years studying the Kurile Islands and this book represents but part of this research.

The Kurile Islands are shown to form a narrow are, unlike the more typical wider systems, which extends $1,200 \mathrm{~km}$ southwards from the Kamchatka Peninsula to the Japanese island of Hokkaido. Over their length the islands form both double and single ares but are untram. melled by the complexities of intersecting systems as are found in Japan.

At the beginning of the book much of the basic geological and geophysical information necessary to appreciate the structure and significance of the arcuate systems is given, including an account of the basement rocks, which are 